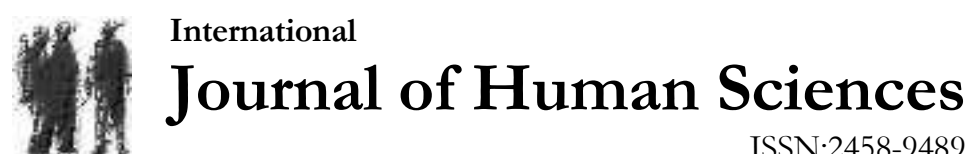

Volume 18 Issue 1 Year: 2021

\section{The effect of organization-public relations on sports fan loyalty}

\author{
Engin Çelebi ${ }^{1}$
}

\begin{abstract}
Public relations practitioners are obliged to facilitate the dialogue between the organization and public. Dialogue plays an important role in sports clubs because the gathering of people from different perspectives and opinions formed by fan groups for a common goal is based on dialogue and tolerance. Public relations theories have important applications for sports clubs to improve their relations with their fan groups. Linking the relational results to the public relations process can contribute to a better understanding of the mission and vision of sports clubs by fan groups and to measure their support. Within the scope of the research, it was aimed to determine the effective strategies necessary for sports clubs to increase the number of fans and their support. In this context, as a result of the research conducted on 176 sports fans, it has been found out that public relations strategies (control mutuality, trust, satisfaction) are the pioneers of fans loyalty. Also, public relations perceptions were found to be a determining factor in supporting behaviors towards sports clubs. Sports fans define their relationship with sports organizations as a communal relationship based on one-sided support rather than an exchange based on mutual benefits. As a result of the research, some suggestions are made for sports clubs to improve the quality of their relations with their supporters' groups.
\end{abstract}

Keywords: Public Relations, Relationship Management, Sports Clubs, Fans Loyalty, Sports and Public Relations

\section{Introduction}

One of the most important resources of sports clubs to achieve their long-term corporate goals is fan group. Effective strategies need to be set in order for sports clubs to increase the number of fans and to receive more support from them. Moreover, collective and inclusive strategies are needed for sports fan groups with different cultural and sociodemographic characteristics. In this study, it's aimed to evaluate the effects of public relations strategies on sports fans' loyalty, acquisition and support, and to reach the results that are measured and evaluated and to contribute to the literature in terms of theoretical and practical aspects.

Kruckeberg and Starck (1988) argued that community building is achieved when people are aware of common goals, are interested in them, and organize their activities according to these

1 Assoc. Prof. Dr., Cukurova University, Vocational School Of Health Services, engincelebi@cu.edu.tr (D) Orcid ID: 0000-0001-5791-8080 
Çelebi, E. (2021). The effect of organization-public relations on sports fan loyalty. Journal of Human Sciences, 18(1), 94103. doi: $10.14687 /$ ihs.v18i1.6080

goals. The authors said that public relations practices would be successful if implemented as an active initiative to acquire and maintain a community sense. The sports industry has an important area in research on these applications. Different strategies may be needed to ensure that groups of sports fans who are formed by gathering people of different perspectives and opinions act in line with a common goal. It can be said that effective communication practices are at the core of these strategies. Sports clubs require relationship management strategies that support two-way communication to build strong relationships with fans.

Supporting a sports club by fans is a motivational force. Sports clubs need fan groups with loyalty and efficient. For this reason, the sports fans have to identify with the organization. It can be said that sports clubs have a long-term (lifelong) relationship with their fans because it is unlikely to change a sports club that is supported.

\section{Relationship Development Strategies In Public Relations}

Public relations strategies provide a theoretical framework for organizations to improve the quality of their relations with important target groups and stakeholders. The purpose of public relations is to build positive relationships with target groups (Ledingham and Bruning, 1998; Hon and Grunig, 1999). Heath and Coombs (2006, p. 7) stated that public relations is "the management function that entails planning, research, publicity, promotion, and collaborative decision making to help any organization's ability to listen to, appreciate, and respond appropriately to those persons and groups whose mutually beneficial relationships the organization needs to foster as it strives to achieve its mission and vision". Public relations practitioners performing a management function offer suggestions on how to improve the quality of relations with the target groups of organizations.

The basis of relationship management focuses on managing public relations to benefit both organizations and public (Cutlip, Center and Broom, 1994). According to Grunig and Jaatinen (1999, p. 219) although the general principles for relational outcomes in public relations are the same for all organizations, the specific conditions under which the principles should be applied may differ. Sports fans constitute a unique group compared to the target groups of other organizations. Therefore, specific relationship development strategies are required.

According to $\mathrm{Ni}$ (2007, p. 54) relationship management research provides a general theoretical framework for measuring the relationships between an organization and its target groups and includes both relationship types and relational quality. Therefore, it is necessary to conduct public relations practices in a relationship-centered manner. According to Yang (2007), focusing on effective relational outcomes with public is very important in public relations practices since it shows the positive reputation of organizations as well as the possibility of maintaining longterm relationships.

\section{Relational Results In Public Relations}

Trust: It can be predicted that a strong sense of trust of sports fans to the management of sports clubs can increase their level of loyalty and their willingness to provide further support. According to Ledingham (2003, p. 185) trust is operationalized as an organization "doing what it says it will do" and it is about the degree to which the organization keeps its promise. Hon and Grunig (1999, p. 3) categorized the concept of trust under three dimensions: "integrity: the belief that an organization is fair and just ... dependability: the belief that an organization will do what it says it will do ... and, competence: the belief that an organization has the ability to do what it says it will do".

Welch (2006, p. 148) stated that academic studies on trust include "confidence, goodwill, faith, integrity, justice, veracity, competence, reliability/dependability, benevolence, risk/vulnerability." Academic studies on distrust include "mistrust, confrontation, guile, selfinterest, lack of confidence, concern about harm, hostile, lack of caring/disrespect, suspicion, intuitive scientist, presumptive/less rational distrust." The author states that feelings of trust and 
Çelebi, E. (2021). The effect of organization-public relations on sports fan loyalty. Journal of Human Sciences, 18(1), 94103. doi: $10.14687 /$ ihs.v18i1.6080

distrust can occur simultaneously. In marketing literature (Morgan and Hunt, 1994) "trust enables the creation of long-term relationships between corporations and their consumers."

Commitment: According to Ledingham (2003), commitment is related to the intention of maintaining the relationship and indicates whether the relationship will continue. According to Hon and Grunig (1999, p. 20) Commitment is "the extent to which one party believes and feels that the relationship is worth spending energy to maintain and promote". According to Author's (p. 20), there are "two dimensions of commitment; continuance commitment, which refers to a certain line of action, and affective commitment, which is an emotional orientation." According to authors, commitment involves both emotional and behavioral intentions, and is believed to be worth spending energy to sustain and promote.

Commitment should consider both attitudinal and behavioral measures. Oliver (1999) states that "there are four sequential stages in the development of loyalty: cognitive, affective, conative and action loyalty." Because commitment is a complex and multidimensional variable that measures repetitive behaviors (Meyer, Allen, 1993; Fiske, 2009). According to Kelleher (2009, p. 176) "Communicated relational commitment indicates - from the perspectives of publics - a type of content of communication in which members of an organization work to express their commitment to building and maintaining a relationship."

Satisfaction: According to Hon and Grunig (1999, p. 20), satisfaction is the measurement of how positive feelings one side feels towards another. When people are satisfied with their relations with an organization, they maintain their relations. Since sports fans can have many different motivations, their satisfaction can be said to be multidimensional. For this reason, it has to be determined what influences the motivation of the sports fans (sense of socialization, the reputation of city or country, identification of sports clubs success with individual success, etc.).

Control Mutuality: According to Hon and Grunig (1999, p. 20), control mutuality shows that "the degree to which parties agree on who has the rightful power to influence one another." Control and power distribution have an impact on organization-public relations. Control mutuality can lead to different perceptions and assessments. According to Marsh (2008, p. 240), the focus on relations and power divisions in potential relations is one of the most common themes in the postmodern critique of public relations theory and practice.

Exchange Relationship: According to Hon and Grunig (1999, p. 20) in the exchange relationship, "one party gives benefits to the other only because the other has provided benefits in the past or is expected to do so in the future." Sports clubs can only see the success of their clubs and thanks to the fans because of their support. However, it should be remembered that sports fans may have desires such as increasing the opportunities of social connection, recognition, reputation, respect, and value.

Communal Relationship: In a communal relationship, both parties benefit from the other without expecting anything in return, because they worry about the welfare of others. In most public relations activities, developing communal relations is more important than developing relations of exchange (Hon \& Grunig, 1999, p. 20). Hung (2005, p. 417) explains that "communal relationships can help an organization develop a win-win relationship with publics because both the organization and publics can benefit to the bighest degree without being exploited." In order to do this, it is necessary to work for a common interest and purpose, to act responsibly (needs identification, etc.), and to balance the concerns (security problem, etc.). For the support of the fans, it can be considered that only the success of sports clubs is enough. However, different missions can be expected such as the contribution of sports clubs to the solution of social problems and their contribution to the development in the region (tourism, etc.).

One of the aims of this study is to determine the relationship types of fan groups with sports clubs. Because it can be said that the relationship types will help determine the intentions of support for sports clubs.

In order to improve the quality of the relational results, it is necessary to act responsibly, fulfill promises and act in a manner worthy of support. Achieving relational results (trust, satisfaction, commitment) requires recognizing individuals and groups of sports fans and demonstrating that their needs and views are valued. For this purpose, beyond expecting the 
Çelebi, E. (2021). The effect of organization-public relations on sports fan loyalty. Journal of Human Sciences, 18(1), 94103. doi: $10.14687 /$ ihs.v18i1.6080

material and moral contributions of the fans group members, it can be used as an integrative strategy to allow them to gain some control over the sports clubs management and to participate in the decision making processes (control mutuality).

\section{Creating Research Questions}

\section{Research}

Marketing literature has shown that the variables of trust, commitment, and satisfaction predict loyalty (Morgan \& Hunt, 1994) and, Zhang et al. (2016) argued, "that loyalty is primarily determined by relationship quality." In this research, it will be investigated whether the trust and satisfaction of the sports fans are the pioneers of their loyalty. Sports fans may not have the same experience and level of loyalty even if they support the same sports clubs. They can have a lot of different motivations, so the first research question was designed to measure the relationship between fans' loyalty to sports clubs and their sense of trust.

Research Question 1: What is the relationship between the degree of trust and loyalty of the fans to sport clubs?

Grunig and White (1992, p. 55) say that organizations that apply excellent public relations include a symmetrical worldview approach. According to the authors, public relations cannot be perfect if organizations have an authoritarian, manipulative and controlling culture. Sports fans may feel that they don't have sufficient say in decision-making and are only responsible for supporting sports clubs. This may cause them to see themselves as a less valuable. Asking for suggestions from fans can help create the feeling that they are involved in decision-making. Being informed about decision-making and sports clubs strategies can help fans think they care. Therefore, the second research question will measure the relationship between the communication process and fans loyalty.

Research Question 2: What is the relationship between the degree of the communication process (control mutuality) and the loyalty of the fans to sport clubs?

As a public attitude, opinions and behaviors are generally accepted as the main results of a public relations program ( $\mathrm{Ki}$ and Hon, 2009). $\mathrm{Ki}$ and Hon (2007, p. 1) found that perceptions of satisfaction and control mutuality developed a positive attitude towards the organization and positive attitudes were the pioneers of supportive behavioral intentions towards the organization. That measurement of mutual benefit should be at the center of public relations assessment, and that measuring mutually beneficial results can help practitioners demonstrate competitive advantages associated with effective public relations practice. In marketing, literature shows that satisfaction is strongly positively related to loyalty (Anderson et al. 1994; Hallowell, 1996; Oliver, 1999). Therefore, the third research question will measure the relationship between loyalty and satisfaction.

Research Question 3: What kind of relationship is there between the satisfaction of the fans and their loyalty to sports clubs?

Jo (2018) investigated which relational results had priority over others and whether there was a cause-effect relationship between these results. The author found that the principle of control mutuality affects trust and satisfaction, satisfaction affects trust, and trust affects commitment. $\mathrm{He}$ stated that trust and satisfaction play a mediating role and participation in the decision-making process through control mutuality will increase the level of trust and satisfaction. The positive feelings of the fans towards the sports clubs are very important for the future of the clubs. The quality of fans' relationship with sports clubs can change emotionally over time. Behavioral intentions have been defined as the intention to perform a particular behavior, the plan to implement the behavior (Perloff, 2003, p. 92). According to Çelebi and Bilir (2019, p. 465) "relational outcomes were important factors for supportive behaviors of sports consumers." In this context, the fourth research question was formed as follows in order to measure the behavioral intentions towards support. 
Çelebi, E. (2021). The effect of organization-public relations on sports fan loyalty. Journal of Human Sciences, 18(1), 94103. doi: $10.14687 /$ ihs.v18i1.6080

Research Question 4: Can the relational outcomes in public relations be used to predict the intention of supportive behavior of fans to sports clubs?

Is the relationship of fans with sports clubs an exchange relationship (reciprocity) or a social (communal) relationship?, to find out that the answer to this question will be sought;

Research Question 5: How do the sports fans define their relationship with sports clubs?

\section{Research Methodology}

Research has been included sports fans in Turkey. The data were collected from the fans on a voluntary basis with the questionnaire technique. The survey was conducted on 176 sports fans. The general profile of the sports fans was taken into consideration and therefore men were mostly included in the research (138 men, 38 women). The reliability of the questionnaire items was tested with a preliminary study on 30 participants. Starting from this preliminary study, minor changes were made to the questionnaire. Data collection took nearly 4 months (February-May 2020).

The reason of the relational results wasn't investigated in the research; the criteria of having a combined ticket and going to the matches were determined in the selection of the fans. In the research, the time required to establish an attitude towards the sports club was determined as 1 year and a questionnaire was applied to the sports fans over the age of 18.

5-point likert-type scale was used for the research scale (1-strongly disagree, 5-strongly agree). Within the scope of the research there're; 5 items for control mutuality (E.g.: This sports club takes care of what the sports fans say), 6 items for the trust (E.g.: Sports club behaves fairly and honestly to the sports fans), 5 items for commitment (E.g.: I prefer to support more to this sports club), 5 items for satisfaction (E.g.: Generally, I am satisfied with the relationship of this sports club) 4 items were used for exchange relations (E.g.: this sports club consensus when it knew that it would win something with its fans), 5 items for communal relations (E.g.: This sport club helps sports fans without waiting for anything in return). Hon and Grunig (1999) developed this scale for the Institute of public relations. The validity and reliability of the scale were accepted in most studies (Hon and Brunner, 2002; Waters, 2008; Ki and Brown 2013; Sisson, 2015; Çelebi, 2108a).

\section{Research Findings}

After the literature review the validity of the questionnaire, which was revised and adapted to the research, was tested using SPSS data techniques. The internal consistency of the questionnaire, that consisted of 30 items, resulted in a very hight level of .878 Cronbach's Alpha. Since the Cronbach's Alpha value of the scale used was high and consistent, the items used in the scales were acceptable.

In order to find an answer to the research question 1, sports fans' trust to the club management and their loyalty to sports club was examined and ".725" coefficients was found between them. This relationship was statistically significant $(t=10.425, p=0.000)$. Therefore, it can be said that there is a statistically significant positive linear relationship between trust and loyalty of sports fans. The results are shown in table 1. 
Çelebi, E. (2021). The effect of organization-public relations on sports fan loyalty. Journal of Human Sciences, 18(1), 94103. doi: $10.14687 /$ jhs.v18i1.6080

Coefficients $^{\mathrm{a}}$

Table 1: Correlation between "trust" and "commitment"

\begin{tabular}{|c|c|c|c|c|c|c|}
\hline \multirow{2}{*}{\multicolumn{2}{|c|}{ Model }} & \multicolumn{2}{|c|}{$\begin{array}{l}\text { Unstandardized } \\
\text { Coefficients }\end{array}$} & \begin{tabular}{|l} 
Standardized \\
Coefficients
\end{tabular} & \multirow[t]{2}{*}{$t$} & \multirow[t]{2}{*}{ Sig. } \\
\hline & & $B$ & Std. Error & Beta & & \\
\hline & (Constant) & 840 &, 285 & & 2,952 &, 004 \\
\hline & Commitmen &, 725 &, 070 &, 620 & 10,425 &, 000 \\
\hline
\end{tabular}

a. Dependent Variable: Trust

For research question 2, how the communication process (control mutuality) affects the level of loyalty of the fans to sports club was measured. According to the results of regression analysis, a significant coefficients (.711) was found between the communication process and loyalty. As can be seen in table 2, the communication process influenced the loyalty levels of the sports fans $(t=11.485, p=0.000)$.

Table 2: Correlation between communication process (control mutuality) and commitment Coefficients $^{\mathrm{a}}$

\begin{tabular}{|ll|l|l|l|l|l|}
\hline \multirow{2}{*}{ Model } & \multicolumn{2}{|l|}{$\begin{array}{l}\text { Unstandardized } \\
\text { Coefficients }\end{array}$} & $\begin{array}{l}\text { Standardized } \\
\text { Coefficients }\end{array}$ & & \multirow{2}{*}{ Sig. } \\
\cline { 2 - 5 } & & $\mathrm{B}$ & Std. Error & Beta & & \\
\hline \multirow{2}{*}{$\begin{array}{l}\text { (Constant) } \\
\text { Commitment }\end{array}$} &, 940 &, 253 & & 3,708 &, 000 \\
\hline
\end{tabular}

a. Dependent Variable: Communication Process (Control Mutuality)

In order to find an answer to the research question 3, the regression analysis was performed and the coefficient between satisfaction and commitment was found,628 and it was statistically significant $(\mathrm{t}=9.881, \mathrm{p}=0.000)$. There is a statistically significant positive linear relationship between satisfaction and loyalty of sports fans. The results are shown in table 3 .

Table 3: Correlation between "satisfaction" and "commitment"

Coefficients $^{\mathrm{a}}$

\begin{tabular}{|ll|l|l|l|l|l|}
\hline \multirow{2}{*}{ Model } & \multicolumn{2}{|l|}{$\begin{array}{l}\text { Unstandardized } \\
\text { Coefficients }\end{array}$} & $\begin{array}{l}\text { Standardized } \\
\text { Coefficients }\end{array}$ & & \multirow{2}{*}{ Sig. } \\
\cline { 2 - 4 } & & S & Std. Error & Beta & & \\
\hline \multirow{2}{*}{1} & (Constant) & 1,396 &, 260 & & 5,366 &, 000 \\
& Commitment &, 628 &, 064 &, 600 & 9,881 &, 000 \\
\hline
\end{tabular}

a. Dependent Variable: Satisfaction

A series of regression analyzes were conducted to search for answers to the research question 4, which was designed to estimate the supportive behaviors of sports fans in relation to sports club. According to the results, relational consequences in public relations can predict $71 \%$ of the supportive behaviors towards loyalty. The results are shown in table 4. 
Çelebi, E. (2021). The effect of organization-public relations on sports fan loyalty. Journal of Human Sciences, 18(1), 94103. doi:10.14687/jhs.v18i1.6080

Table 4: The effect of relationship development strategies on supportive behaviors towards commitment

Model Summary $^{\mathrm{b}}$

\begin{tabular}{|c|c|c|c|c|c|c|c|}
\hline \multirow[t]{3}{*}{ Model R } & & \multirow{3}{*}{$\begin{array}{l}\mathrm{R} \\
\text { Square }\end{array}$} & \multirow{3}{*}{$\begin{array}{l}\text { Adjusted } \\
\text { Square }\end{array}$} & \multirow{3}{*}{ 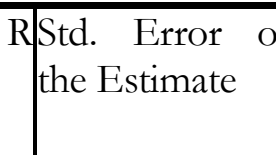 } & of Change Statistics & \multicolumn{2}{|r|}{ Durbin- } \\
\hline & & & & & \begin{tabular}{|l|l|}
$\mathrm{R}$ & Square \\
\end{tabular} & \begin{tabular}{|l|l|l} 
df1 & df2 & Sig.
\end{tabular} & \\
\hline & & & & & Change & Change & \\
\hline 7 &, 713 &, 508 &, 499 &, 50568 & 59,162 & \begin{tabular}{|l|l}
3 & 172,000 \\
\end{tabular} & 1,553 \\
\hline
\end{tabular}

a. Predictors: (Constant), Control Mutuality, Satisfaction, Trust

b. Dependent Variable: Commitmetn

Furthermore, according to the analyzes, a significant correlation was found between the loyalty of the sports fans and duration. The results are shown in table 5.

Table 5: Comparison of the loyalty levels of sports fans according to duration

\begin{tabular}{|l|l|l|l|}
\hline Duration & Mean & $\mathrm{N}$ & Std. Deviation \\
\hline $1-3$ years & 4,0035 & 57 & 65081 \\
$4-6$ years & 4,0982 & 55 & 66732 \\
$7+$ & 4,1969 & 64 & 71580 \\
Total & 4,1034 & 176 &, 68718 \\
\hline
\end{tabular}

When the loyalty levels of sports fans to sports club were compared according to duration time, the loyalty rates of the sports fans who continued their activities for more than 7 years were found to be higher.

\section{Conclusion And Discussion}

In this study, it was aimed to determine the effective strategies required for increasing the loyalty of the sports fans, which is one of the most important gains of the sports clubs. The relationship between the relational dimensions of public relations and the behaviors, perceptions and attitudes of the sports fans towards their loyalty were analyzed.

Trust: Trust is a central factor in creating loyalty in relationship literature (Morgan \& Hunt, 1994). The most important factor was measured as the "trust" among the relational results for the sports fans loyalty. In addition, the research revealed that trust in sports clubs is the most important factor for supportive behaviors of fans. Therefore, sports clubs should look for ways to increase the trust of their fans. Similarly, Hon and Brunner (2002), in their study of 468 people at the University of Florida, revealed that all elements of trust are involved in honesty and care. It can be said that there is a strong relationship between trust and the intention of fans to continue to spend their time and energy for the success of sports clubs.

Satisfaction: Relational satisfaction indicates how mutually satisfied both sports clubs and their fans are. Acoording to Çelebi (2018b) the "commitment" dimension is more valuable than the others in sports industry. Motivating features such as gaining reputation and being recognized and appreciated can contribute to an increase in the satisfaction level of the fans. According to Lievens (2007, p. 56), corporate image and corporate identity have psychological and social realities and can have important consequences for organizations. Therefore, the corporate identity and image of sports clubs must meet expectations for individual goals (e. g. linking to success). On the other hand, customer relations studies have stated that customer satisfaction will not create customer loyalty. According to Oliver (1999) "consumer loyalty and satisfaction are linked in extracibisy", but "although loyal consumers are most typically satisfied, satisfaction does not universally translate into loyalty." Also, according to Jones and Sasser (1995) customer satisfaction alone does not determine customer loyalty. Therefore, relational satisfaction should be considered together with other relational results. 
Çelebi, E. (2021). The effect of organization-public relations on sports fan loyalty. Journal of Human Sciences, 18(1), 94103. doi: $10.14687 /$ ihs.v18i1.6080

Control Mutuality: In order to build control mutuality related to internal democracy, the structure of sports clubs should involve the fans in the information flow process and give them opportunities to make decisions. Feedback, opinions and suggestions should be taken into account, which requires a convincing, open, direct and active dialogue with the supporters' groups. Fans are very important for sports clubs, that's why their needs and concerns must be understood well. Moreover, an understanding of "from match day to every day" fan engagement is also important so that they would feel themselves valuable. Since the principle of participation increases trust, it should be taken into account in the decision- making process of public relations practices in sports clubs for the planning and persuasive communication strategy. Sports clubs are exploring effective strategies to increase the number of their fans and get more support from them. For this, the clubs need to understand fans and meet their expectations in a comprehensive way. Understanding subjective perceptions and expectations is as important as understanding relational outcomes. Subjective opinions can be determined according to the type of relations. Therefore, measuring the values shown to expectations through measurement can help to prepare public relations practices effectively.

Exchange Relationship: We can define the relationship of sports clubs with the fans as an asymmetric relationship. We can state that this relationship depends on personal motivation. Exchange relationship requires an understanding of fans' needs and concerns for relationships. It is not right to expect the fans not to ask for anything from sports clubs in return for their support. It is not fair to expect the fans not to ask for anything from sports clubs in return for their support. Opportunities should be provided to create a balance of interest, support the fans to lead an active life, create opportunities for social connection and increase their motivation to feel good.

Communal Relationship: It is for people who work for a common purpose without expecting anything in return for communal relations. Communal relations require acting together for social benefit based on the principle of equality. In order to work for social benefit, team spirit must be created. The contribution of sports clubs to the reputation of the city, region or country and to the economic return contributes to the development of relational results. It can be said that sports clubs especially target young people. Establishing active and quality programs for young people both during and outside of game times, contributing to the increase of their social engagement and enabling them to act together for a common purpose can increase their loyalty.

Public relations practitioners are obliged to facilitate the dialogue between the organizations they represent and their public. Dialogue plays an important role in sports clubs. Because bringing different people together for a common purpose is based on dialogue and tolerance. The fact that different ideas come together and work for a common purpose may serve as an example for other organizations.

In sports clubs, participation of fan groups in the process of creating public relations practices will increase communicative efficiency. Developing relationships requires recognizing fan groups and showing that they are valued. Regular communication with the fan groups, informing them and developing dialogue may positively affect the quality, trust, commitment and satisfaction of the sports clubs' relations with their fans.

Grunig and Huang (2000, p. 36) stated that their relationship strategies based on interpersonal communication are to create positive emotions, to give confidence, to share tasks, to be open (transparency), to create shared networks, and to provide access. Revealing the expectations and motivating characteristics of the groups of fans towards these relational strategies towards individual and group goals may contribute to the development of relational outcomes. Sports fans groups should be informed about transparency and accountability. Their past experiences, needs, concerns, characteristics, and abilities should be taken into consideration. Appropriate communication strategies should be determined, and inclusive environments should be developed. Team spirit should be created.

To attaching value to the fans' views, involving them in the decision-making process is effective for retaining supporters. Fans' loyalty is one of the most important attitude variables in 
Çelebi, E. (2021). The effect of organization-public relations on sports fan loyalty. Journal of Human Sciences, 18(1), 94103. doi: $10.14687 /$ jhs.v18i1.6080

protecting relationships. According to Pressgrove and McKeever (2016, p. 200), cognitive, affective, and behavioral loyalty should develop behavioral support in such non-profit organizations. Strategies such as engaging in dialogue, requesting regular feedback, demonstrating that opinions and suggestions will be evaluated, and implementing them contribute to the continuation of the relational results and improving the quality. Also, interpersonal communication (face-to-face communication) has significant effects on opinions and behaviors. Therefore, we can say that interpersonal communication should be included in all public relations practices.

To discuss concerns, views, and opinions, sports fan groups should have the opportunity to interact and dialogue, find common aims and develop a sense of community. When steps towards concerns and thoughts are taken, fan groups may feel valued and respected by sports clubs. This situation allows their support to continue.

Loyalty focuses on long-term relationships and reflects the belief that the relationship is worth sustaining. In order to gain fan groups' loyalty, which means a strong future for sports clubs, individuals should be made to feel that their assets and support are valuable. It can be said that a multifaceted strategic approach may be required to reach a result such as loyalty. To understand what is beneficial for fan groups and to learn positive emotional and behavioral effects, it is necessary to learn what affects and develops loyalty. Requesting regular feedback from fans, ensuring clear and transparent information flow, demonstrating that their opinions and suggestions are taken into consideration, and ensuring their participation in decision-making can affect their motivation for loyalty.

It can be said that the transparency, quality, and quantity of the communication process with the fan groups can create a sense of commitment. Such interpersonal communicative processes are a method of developing a relationship in public relations. Also, it is necessary to focus on the reputation and image of the sports fans profile of the represented sports club, to create a family environment, to pay attention to behavioral relationships and to ensure reliability against corporate governance.

Motivating characteristics, cultural and socioeconomic differences that might affect fans were not investigated within the scope of the research. Causes such as time spent on family life, work life, and social life may affect the factors of fans. Future research should investigate the effects of these situational factors on sports fans, taking into account emotional and behavioral variables. Moreover, it should be noted that relational results are dynamic results that can change over time (Broom et al., 1997; Ledingham, 2003). Future research should explore how these relational outcomes occur and may change.

\section{References}

Anderson, E.W., Fornell, C. \& Lehmann, D.R. (1994). Customer satisfaction, market share, and profitability: Findings from Sweden. Journal Of Marketing, Vol. 58, 53-66.

Broom, G. M., Casey, S. \& Ritchey, J. (1997). Toward a Concept and Theory of OrganizationPublic Relationships. Journal Of Public Relations Research 9(2), 83-98.

Cutlip, S. M., Center, A.H. \& Broom, G.M. (1994). Effective Public Relations. Upper Sadddle River, NJ: Prentice-Hall.

Çelebi, E. (2018a). Measuring the Effectiveness of Organizational Public Relations: An Experimental Research on Crisis Response Strategies. Journal of Communication Theory \& Research / Issue 46, 275-290.

Çelebi, E. (2018b). Measuring Effectiveness Of Relationship Management In Public Relations: A Research On Sport Clubs. International Conference On Management, Economics \& Social Science - ICMESS 2018, Proceedings Of Researchfora International Conference, Copenhagen, Denmark, 1-4. 
Çelebi, E. (2021). The effect of organization-public relations on sports fan loyalty. Journal of Human Sciences, 18(1), 94103. doi: $10.14687 /$ ihs.v18i1.6080

Çelebi, E. \& Bilir, F.P. (2019). Effects Of Relationship Management On Sports Consumers: A Research On Private Sports Centers. in: Recent Advances in Social Sciences, Eds. by. Efe, R., Koleva, I., Öztürk, M., and Arabac1, R., Cambridge Scholars Publishing, Newcastle, 452468.

Çelebi, E. (2020). Public relations in public institutions: A research on the effectiveness of communication process. Journal of Human Sciences, 17(3), 768-779.

Fiske, S.T. (2009). Social Beings: Core Motives in Social Psychology. Second Edition, Willey.

Hallowell, R. (1996). The relationships of customer satisfaction, customer loyalty, and profitability: An empirical study. International Journal of Service Industry Management, Vol. 7 No. 4, $27-42$.

Heath, R. L. \& Coombs, W.T. (2006). Today's public relations, California: SAGE.

Hon, L. \& Brunner, B. (2002). Measuring public relationships among students and administrators at the University of Florida. Journal of Communication Management, Vol. 6 Iss 3, 227-238.

Hon, L.C. \& Grunig, J.E. (1999). Guidelines for Measuring Relationships in Public Relations. Institute for Public Relations, 1-40.

Hung, C. F. (2005). Exploring Types of Organization-Public Relationships and Their Implications for Relationship Management in Public Relations. Journal of Public Relations Research, 17:4, 393-426.

Grunig, J. E. \& Huang, Y. H. (2000). From organizational effectiveness to relationship indicators: Antecedents of relationships, public relations strategies, and relationship outcomes. In J. A. Ledingham \& S. D. Bruning (Eds.), "Public relations as relationship management: A relational approach to public relations" (pp. 23-54). Mahwah, NJ: Lawrence Erlbaum Associates.

Grunig, J. E. \& Jaatinen, M. (1999). Strategic, symmetrical public relations in government: From pluralism to societal corporatism. Journal of Communication Management, Vol. 3(3), 218234.

Grunig, J. E. \& White, J. (1992). The effect of worldviews on public relations theory and practice. In J. E. Grunig (Ed.) "Excellent public relations and communication management" (pp. 31-64). Hillsdale, NJ: Lawrence Erlbaum Associates.

Jo, S. (2018). In Research of Causal Model of The Organization-Public Relationship In Public Relations. Social Behavior and Personality, 46(11), 1761-1770.

Jones, T. O. \& Sasser, W. E. (1995). Why satisfied customers defect. Harvard Business Review 73, $88-89$.

Kelleher, T. (2009). Conversational voice, communicated commitment, and public relations outcomes in interactive online communication. Journal of Communication 59, 172-188.

Ki, E. \& Brown, K. A. (2013). The Effects of Crisis Response Strategies on Relationship Quality Outcomes. Journal of Business Communication, Vol. 50, No. 4, 403-420.

Ki, E. \& Hon, L.C. (2007). Reliability and Validity of Organization: Public Relationship Measurement and Linkages Among Relationship Indicators In a Membership Organization. Journalism \& Mass Communication Quarterly, Vol. 84, No. 3, 430-431.

Ki, E.J. \& Hon, L. C. (2009). The causal linkages between/among relationship cultivation strategies and relationship quality outcomes. International Journal of Strategic Communication 3:4, 242-263.

Kruckeberg, D. \& Starck, K. (1988). Public relations and community: a reconstructed theory, New York, Praeger.

Ledingham, J.A. (2003). Explicating Relationship Management as a General Theory of Public Relations. Journal of Public Relations Research, Vol. 15, No. 2, 181-189.

Ledingham, J.A. \& Bruning, S.D. (1998). Relationship Management in Public Relations: Dimensions of an Organization Public Relationship. Public Relations Review, Vol. 24, No. 1, 55-65. 
Çelebi, E. (2021). The effect of organization-public relations on sports fan loyalty. Journal of Human Sciences, 18(1), 94103. doi:10.14687/jhs.v18i1.6080

Lievens,F., Hoye, G. Van, Anseel, F. (2007). Organizational Identity and Employer Image: Towards a Unifying Framework. British Journal of Management, Vol. 18, 45-59.

Marsh, C. (2008). Postmodernism, symmetry, and cash value: An Isocratean model for practitioners. Public Relations Review, Vol. 34, 237-243.

Meyer, J.P. \& Allen, N. (1993). Commitment to Organizations and Occupations: Extension and Test of a Three-Component Conceptualization. Journal of Applied Psychology 78(4), 538551.

Morgan, R. M. \& Hunt, S. D. (1994). The commitment-trust theory of relationship marketing. Journal of Marketing, Vol. 58, No. 3, 20-38.

$\mathrm{Ni}$, L. (2007). Refined understanding of perspectives on employee-organization relationships: Themes and variations. Journal of Communication Management, Vol. 11 Issue: 1, 53-70.

Oliver, R.L. (1999). Whence Consumer Loyalty?. Journal of Marketing, Vol. 63, 33-44.

Perloff, R. M. (2003). The dynamics of persuasion: Communication and attitudes in the 21st century. (2nd ed). Mahwah, NJ: Lawrence Erlbaum Associates, Inc.

Pressgrove, G. N. \& McKeever, B.W. (2016). Nonprofit relationship management: Extending the organization-public relationship to loyalty and behaviors. Journal of Public Relations Research 28:3-4, 193-211.

Sisson, D. C. (2015). Authentic Relationship Management to Heighten Control Mutuality in Social Media. Doctoral dissertation, Retrieved from http://scholarcommons.sc.edu/etd/3608.

Yang, S-U. (2007). An Integrated Model for Organization-Public Relational Outcomes, Organizational Reputation, and Their Antecedents. Journal of Public Relations Research 19:2, 91-121.

Waters, R.D. (2008). Applying relationship management theory to the fundraising process for individual donors. Journal of Communication Management, Vol. 12 Issue: 1, 73-87.

Welch, M. (2006). Rethinking relationship management: Exploring the dimension of trust. Journal of Communication Management, Vol. 10 Issue: 2, 138-155.

Zhang, K.Z.K., Benyoucef, M., Zhao, S.J. (2016). Building brand loyalty in social commerce: The case of brand microblogs. Electronic Commerce Research and Applications 15, 14-25. 